\title{
Language and Globalization: A Critical Analysis of Global Economy in Strategic Texts during the Financial Crisis
}

\author{
Mustafa $\mathrm{Ar}^{1}$ \\ ${ }^{1}$ Department of English Language, Ar-Raniry State Islamic University, Aceh, Indonesia \\ Correspondence: Mustafa Ar, Department of English Language, UIN Ar-Raniry, Banda Aceh 23111, Indonesia. Tel: \\ 62-651-755-2922. E-mail: mustaryus@gmail.com \\ Received: April 6, 2015 \\ Accepted: April 27, 2015 \\ Online Published: April 30, 2015 \\ doi:10.5430/elr.v4n2p1 \\ URL: http://dx.doi.org/10.5430/elr.v4n2p1
}

\begin{abstract}
Free-market economists assert that global economy is material processes forced by and promote transborder flows of capital, goods and services. This unprecedented phenomenon was affected by the global financial crisis emerging in 2008. During the financial turmoil, global economy is still discursively reconstructed and politically argued for. However, few studies have explored the dialectical relationship between discourse and global economy during the financial crisis. The purpose of this paper is to discuss the way globalization, especially the global economy is discursively constructed in strategic texts in the period of global financial crisis. By applying Critical Discourse Analysis (CDA) and the pragma-dialectical approach to argumentation, this paper analyzes political economic speeches of George Bush and Wen Jiabao and Opinion-Editorial articles from the Washington Post and the China Daily. As a result of the transdisciplinary analysis, the paper reveals that the project of global economy must be maintained even in the epoch of financial crisis. The argumentative discourse of global economy during the financial crisis is characterized by problem-solution structures. The authors also advanced their arguments based on selected topics that are easy to handle and most agreeable to discourse participants. The discourse of global economy defends the ideology of capitalist globalization. The paper suggests that there be a need for public awareness of both the material and discursive processes of globalization.
\end{abstract}

Keywords: Argumentation, Critical discourse analysis, Financial crisis, Globalization, Pragma-dialectical, Strategic texts

\section{Introduction}

Globalization is an unprecedented and seriously debated phenomenon. It is often trapped in economic provisos which are regarded as the broadening and deepening linkages of national economies into a worldwide market for capital, goods, and services. Globalization has also been seen in both positive and negative senses. Positively, globalization is regarded as a new way of interaction concerning free trade, market liberalization, and flows of capital among nations (Held, McGrew, Goldblatt \& Perraton, 1999). Negatively, globalization is an inevitable myth that offers particular perspective on the global trading and financial order and dismisses other perspectives by declaring them as unrealistic or unfeasible (Hisrt \& Thompson, 1996). To put it differently, globalization in the context of critical scholarship (Sparke, 2013; Fairclough, 2010; Peck \& Theodore, 2007; Scholte, 2000) is virtually an ideology of political economy created by capitalist discourse that promotes and operates on the principle of free movements of goods, capital, information and services between countries. Although this conception of economic globalization is vulnerable to ramification, it is still formidably shared among supporting groups of globalizing economists, state leaders, corporate managers, commercial circles and many journalists. The way of internalizing this discursive practice is not neutral; it attaches political and social beliefs to the economic system of capitalists who have access to exercise power and dominate the system of global economy.

Consequently, since the emergence of globalization debate in the 1990s (e.g. Hisrt \& Thompson, 1996), the relationship between language (discourse) and social realities - discourse and the reality on global economy and of its impacts on, manifestations and ramifications-has become a burgeoning field of scientific inquiry. The interdependence between these aspects has drawn attention from a number of academic disciplines, such as political economy, sociology, and critical linguistics. Although globalization research virtually falls within the field of political economy, some critical discourse analysts also seem to have currently paid their attention to this phenomenon (e.g. Fairclough, 2006; Monica, 2003; Flowerdew, 2002). They agree that globalization as an economic, 
political and social phenomenon cannot entirely be separated from discourse, because the two aspects are dialectically related (Fairclough, 2006). They observe that it is through discourse or other semiotic practices that a particular social reality, such as global economy can socially be constructed (Fairclough, 2006, 2010). However, although there is a body of literature that addresses globalization from a discursive dimension, they often lack evidence from textual analysis (e.g. Koh, 2005; Hay \& Rosamond, 2002). There is thus a need for a transdisciplinary approach at least between political economy, sociology and CDA to unraveling the issue scientifically.

This article therefore approaches economic globalization from a (transdisciplinary) CDA perspective (Fairclough, 2006); a version of CDA that commits to conducting a dialogue with other disciplines - political economy (Jessop, 2004), argumentation (van Eemeren \& Grootendorst, 2004) and systemic functional linguistics (Halliday \& Matthiessen, 2014). Fairclough (2003) asserts that discourse is a moment of networks of social practices; it is social acts of people doing, talking and writing things; it is a particular way of representation, of meaning-making in conjunction with other practices, such as promoting free trade. According to Fairclough (2014) globalization project is a good but an incomplete process. He thus sees discourse of globalization as social practice that has a dialectical relationship between the discursive processes and material social processes (Fairclough, 2006). Social practice does not only reflect reality, but it also can change reality. Social practice which is created in a particular way constitutes a social order, such as an economic order in a particular society at a particular space and time (Chouliaraki \& Fairclough, 1999).

This study attempts to especially examine the discursive construction of global economy in strategic texts. What is meant by a strategic text is a discourse type (Fairclough, 2003) that is specifically concerned with the systems of political economy, government policies and plans, and the ways these elements are strategically embedded in genres such as newspaper articles. Vaara, Sorsa \& Pälli (2010) use a nearly similar term 'strategy text', referring to a text type which deals with organizing strategies for a city plan in Finland that is textually constructed in genres which include interviews and presentation slides. They relate the term strategy text to language-based organizing activities whereas this study uses the term strategic text, inspired by Fairclough (2003, p. 199), to refer to the discursive representation of global economy that involves political economy, social belief systems, state policies, and planned economic strategies. A strategic text has an economic and political nuance. The strategic texts analyzed in this article are newspaper Opinion-Editorials (Op-Eds) and political speeches.

The main objective of study is to analyze how an author-defined as a writer or speaker who produces text-discursively constructs global economy in the strategic texts. A special reference is made to the strategic texts during the 2008 global financial crisis. The study is thus guided by the following research questions: 1). How do the authors construct the discourse of global economy in the strategic texts during the global financial crisis? 2). How do the authors organize their arguments in the strategic texts during the global financial crisis? 3). How do the authors use argumentation strategies to construct the discourse of global economy in these texts?

\section{Literature Review}

Relatively few previous studies have systematically examined the discursive processes of globalization during the financial crisis. Fairclough \& Fairclough (2011) seek to incorporate practical reasoning into CDA and analyze the UK government's 2008 Pre-Budget Report as an illustration. Their study was primarily aimed at revisiting the research paradigm for critical analysis of discourse. Kutter (2014) studied the discursive construction of the Greek financial crisis in the German financial press. She found that the discursive representation of the Greek crisis was used to catalyze the reform of the European Economic and Monetary Union and to reinforce economic integration. Many other scholars have in effect focused on material processes of globalization. They assert that globalization is a process triggered by and gives rise to increasing transborder flows of goods, money, services, people, information, and culture. Globalization is "a process (or set of processes) which embodies a transformation in the spatial organization of social relations and transactions... generating transcontinental or interregional flows and networks of activity, interaction, and the exercise of power" (Held et al., 1999, p. 16). The flows, networks and interconnections are generally diverse in character, including: flows of goods and money and international financial and trading networks in the economic field; inter-governmental networks and interdependencies and interactions and interconnections between international agencies such as the United Nations, the International Monetary Fund, the World Bank, and the World Trade Organization and government agencies at national and regional levels (Fairclough, 2006). These global processes also include the mobility of people as migrants, tourists, or members of commercial or governmental organizations; flows of images and representations and interactions through contemporary media and forms of technology and so forth. In brief, all the ideas about globalization are concerned to a large extent with a 
process leading to greater interdependence and mutual understanding among economic, political, and social institutions in the world, and agencies in general as well as advance in technology.

Globalization, as indicated above, has essentially been discussed more in the context of economy than in any other perspective. For example, the Japanese corporate management guru, Kenichi Ohmae (1994) describes globalization as an imaginatively world-scaled business opportunity. Sociologist Anthony Giddens (1990, p. 63) regards globalization as consequence of modernity as he puts it, "modernity is inherently globalizing" and as a decoupling or "distanciation" between space and time. Sociologist Manuel Castells (1996, p. 92) also emphasizes the economic aspects of the globalization as he defines it as "an economy with the capacity to work as a unit in real time on a planetary scale." Sociologist Gary Gereffi (1994) writes about global "commodity chains," whereby production is coordinated on a global scale. Political scientist Robert Gilpin (1987, p. 389) defines globalization as the "increasing interdependence of national economies in trade, finance, and macroeconomic policy." In a similar vein, other scholars (Held et al., 1999; Ritzer, 2009; Adams, 2011) also point out that the reality of globalization is a continuous economic process driven both by fundamental economic policy changes by individual governments and by technological innovation. New emerging-economy countries and sources of supply of and demand for an ever-increasing number of goods and services are being integrated at an accelerating tempo into a global economy (Ohmae, 1994). As such, it is often claimed that globalization is an inclusive process through which emerging countries like China and India join the developed nations as increasingly integrated "equal partners" in the now so-called global economy. Some people raise questions whether globalization is truly a new phenomenon under the sun. They contend that the entire course of human history can be seen as the gradual expansion of transportation and communication networks; in that context, globalization may be little more than an extension of past patterns of human interaction (Sparke, 2013; Scholte, 2000; Bauman, 2013). This process of dominance is virtually comes under the sense of internationalization. However, internationalization has existed for centuries; globalization is an idea whose time has come (Held et al., 1999). And since it embraces every angle of political economy, globalization should be seen more than enhanced internalization of human interaction if the process is to be more distinctive and meaningful (Hirst \& Thompson, 1996). What is absent from these multiple-complex perspectives is a viewpoint that includes text as part of globalization processes.

For the sake of studying globalization from its linguistic domain, it is therefore reasonable to add another standpoint that globalization is an ideological project for the expansion of power with multiple meanings and perspectives. It is linguistically a process of re-semanticization of the word global through the use of metaphor (Hasan, 2003) that gives rise to emergence of ideologies founded on the principles of free movements of capital, goods \& services, and information as well as the abolition of government intervention in economic affairs: no restrictions on manufacturing, no barriers to commerce, no tax and tariff on import. Stated in a more polished form, globalization is both the processes of representing imaginaries in discourse and making them actualize in material manifestation. In other words, globalization is both a material phenomenon and a political project (Sparke, 2013).

This paper also sees globalization from an economic perspective and treats it as a particular facet of discourse. Globalization is a social manifestation and discourse practice is of social manifestation as well. The discourse of globalization is a subject of social construction in response to social realities. In other words, discourse is the vital character in constructing economic realities. But discourse of globalization is a complex social issue. We thus need to combine CDA with political economy to extend the theory of the relationship between discourse and globalization which is so-called transdisciplinary (Fairclough, 2010). This adoption is derived from the standpoint that economic systems are politically embedded in text and that both political and economic objects are initially discursively constructed (Jessop, 2004; Fairclough, 2006). The combination between CDA and political economy will assist us in the analysis of concrete examples from an emerging economic country and an industrially advanced one - notably China and the USA - to show how political economy can be incorporated into the analysis of texts. The paper contends that social reality and discourse have a two way relationship; they embody each other. In other words, social realities are partly discourse. Discourse does not exist independently from the world of objects it represents; they are different but not discrete (Fairclough, 2006). The paper thus attends to 'globalization' with the oscillating analysis in which a dialogue across disciplines is put to work when looking at the social problem, i.e., the global financial crisis. The analysis of strategic texts is motivated by this conception.

\section{Methodology}

\subsection{Analytical Framework}

This paper draws upon CDA and argumentation for its analytical framework. Fairclough's version of CDA and its reference to SFL's lexico-grammar (Halliday \& Matthiessen, 2014) for textual analysis is used. The argumentation 
theory that is applied in the current study is the pragma-dialectical approach (van Eemeren \& Grootendorst (2004). CDA is put to work with argumentation studies without the former being reducible to the latter (Fairclough, 2010; Chouliaraki \& Fairclough, 1999; Fairclough \& Fairclough, 2011). To bring these disciplines into a more solid dialectical relation, we can refer to the argumentation structure and strategic maneuvering conceptualized by the pragma-dialectical theory of argumentation (van Eemeren, 2010).

The pragma-dialectical approach sees argumentation as a social, verbal activity, which can be performed orally as well as in writing. The foremost task of an analyst is to examine the standpoint, the argument structure and the rhetorical strategies. Genres such as an OP-Ed article or a political speech must have a standpoint, argumentative structures and ways of persuasion. Typical of such genres is that discourse participants (or speakers and hearers) may or may not share similar points of view. In the argumentative discourse of such a situation the discourse producer then tries to make his or her standpoint more acceptable, credible or truthful by formulating 'arguments' that are purported to sustain the chosen point of view. Argumentation on global economy must have a standpoint. An author can adopt a positive, negative or neutral standpoint. For example, when an author asserts that 'I think globalization is an unprecedented phenomenon', in that the author has adopted a positive standpoint with respect to the proposition that globalization is an unprecedented phenomenon. An author can alternatively say that 'I do not think globalization is an unprecedented phenomenon, in that the author has adopted a negative standpoint. An author can also even state that 'I do not know whether globalization is an unprecedented phenomenon', in that the author has not committed $\mathrm{him} / \mathrm{h}$ erself to this proposition in a positive or negative way because he/she is not sure about it. In that case, the author is taking a neutral standpoint. Whether it comes first or later, the standpoint is identifiable in either at the argumentation stage or concluding stage (van Eemeren, Grootendorst \& Henkemans, 2002). The role of authors in argumentation is to defend the standpoint that they have adopted. Since an argumentative discourse is exchanged around an adopted standpoint, identifying the way the point is manifested is important in analyzing the discursive construction of global economy during the financial crisis.

An argumentative discourse generally has a rational structure. Whether or not argumentation structures vary with an ideological position is still a quest. The content of an argumentation however may depend on the ideology one believes in. And 'good' and 'bad' argumentation is rather something that varies with individual speakers than with group membership (van Dijk, 2009). Of course, like any genre, various argumentative discourses may be learned and be associated with a profession and hence with professional ideologies. An influential politician, leading economist or newspaper columnist is probably more experienced in 'good' argumentation than those who do not have such professional training and experience. Discourse and argumentation structures may relate to one's expertise attained through education, training and experience.

The aim of the parties (proponent and opponent) to be involved in argumentative discourse is to find out ways of resolving a difference of opinion. This implies that the parties are obliged to abide by the rules instrumental in achieving the argumentation goal by maintaining a certain standard of reasonableness (van Eemeren \& Grootendorst, 2004). As is the case for many genres, such as an Op-Ed article or political speech, argumentation is controlled by a number of normative rules, interaction principles and efficient strategies of actual performance. Some of these normative rules are: 1). the proponent who puts forward a standpoint is to defend it; 2 ). the proponent may defend his or her standpoint only by advancing the argumentation related to that standpoint; and 3). the reasoning in the argumentation must be logically valid or must be capable of being made valid (van Eemeren et al., 2002; van Eemeren \& Grootendorst, 2004). In reality, of course, one may break the rules of argumentation, for instance by using fallacies, false moves in the arguments, but still respect interaction principles (for instance of respect or cooperation) and still be a very efficient arguer (van Eemeren, 2010).

However, interacting in such a way does not mean that the parties cannot resolve the difference of opinion in their own favor. To put it differently, the parties involved in a critical discussion can use rhetorical means in argumentative discourse as long as they maintain the rules of the discussion and they must be responsible for what they say or imply. Central to the analysis of argumentative discourse, therefore, is also the role of rhetorical dimensions that are conceived as strategic maneuvering for influencing result of argument. The strategic maneuvering manifests in three ways. The first strategy is called topical selection, in which the arguers make a convenient choice from the options. The arguers may choose the materials they find easiest to handle. They introduce the particular topics that are important and relevant to the discussion, which can work to provide the disagreement space of each dialectical stage to the benefit of the proponent. The second strategy is adaptation to audience demand, in which the arguers will choose the perspectives they think most agreeable to the audience. They try to create empathy with the audience through appeal to audience's beliefs, common senses or preferences. The third strategy is presentational choices, in which the arguers choose the rhetorical repertoire, which can frame their contribution in 
the most effective ways. They can choose the presentational devices, such as loaded definitions, generalizations and rhetorical argumentative structure (van Eemeren, 2010). In brief, the analysis of argumentation together with CDA contributes to better understanding the linguistic and social processes of constituting the practices of global economy.

\subsection{Sources of Text for Analysis}

China and the USA becomes the research site for the sources of strategic texts. This consideration is taken based on the principle that we cannot even think about globalization or discuss it effectively without reference to specific locations and places (Beck, 2000). For each of the two countries the strategic texts are classified into two categories: the Op-Ed articles from print media and speeches. The two modes of genre are chosen to avoid the privilege of one genre over the other. Four texts have been chosen to represent the research site and the mode of genre. The print media texts came from the China Daily to represent China the Washington Post to represent the USA. The Op-Ed articles in these newspapers are usually contributed by well-known figures. The China Daily, which was established on June 1, 1981, is the most influential national English-language newspaper in China and circulated abroad in more than 150 countries and regions. It is not only the most widely circulated Chinese newspaper among the majority of Western readers but also the most frequently quoted Chinese newspaper by international news media. According to its website source, the China Daily is often called the "Voice of China" or "Window to China", because it is regarded as one of the country's most authoritative English media outlets and an important source of information on Chinese politic, economy, society and culture. For a basic reason, the China Daily is chosen because it transmits China's national images, politic, and foreign policy to the international community. The Washington Post is chosen because its positions on foreign policy and economic issues are of a definitively conservative stance. For example, it advocates free trade agreements. Meanwhile, the speeches were also delivered by influential figures on several occasions. To represent China, I choose a speech by Wen Jiabao. Premier Wen Jiabao delivered the speech in Chinese, but this study refers to the English version of the speech which was authoritatively prepared by the government of China. For the U.S. counterpart, a speech by George Bush was selected. The criteria of text selections are the period of publication and the issues raised in the texts.

\section{Excerpts and Analysis}

\subsection{Discourse of Global Economy during the Financial Crisis}

The material processes of global economy were interrupted by the 2008 financial crisis. The world economy was not progressing as it had been discursively practiced. This indicates that no economic system is resistant for all time. Even the neoliberal global economy is at risk. The following excerpts reveal that the global market economy can also suffer from a financial crisis. I underline the linguistic elements I find highly pertinent to the topic under discussion.

(1) The Financial Crisis Is Also an Opportunity to Create New Rules for Our Global Economy. (headline)

We are living through the first financial crisis of this new global age. And the decisions we make will affect us over not just the next few weeks but for years to come. [para. 2] (...)

We are all in this together, and we can only resolve this crisis together. If we do this, 2008 will be remembered not just as a year of financial crisis but as the year we started to build the world anew. [para. 11] (Washington Post, October 17, 2008)

(2) And today I appreciate you giving me a chance to come and for me to outline the steps that America and our partners are taking and are going to take to overcome this financial crisis. [para. 1] (...)

The financial crisis was ignited when booming housing markets began to decline. As home values dropped, many borrowers defaulted on their mortgages, and institutions holding securities backed by those mortgages suffered serious losses. [para. 10] (...)

This is a decisive moment for the global economy. In the wake of the financial crisis, voices from the left and right are equating the free enterprise system with greed and exploitation and failure. [para. 26] (George Bush, November 13, 2008)

(3) Protectionism has swept across the world in the face of the financial crisis. (China Daily, April 02, 2009, para. 3)

(4) This annual meeting has a special significance. Amidst a global financial crisis rarely seen in history, it brings together government leaders, business people, experts and scholars of different countries to jointly explore ways to maintain international financial stability, promote world economic growth and better address global issues. [para. $1](\ldots)$ 
The ongoing international financial crisis has landed the world economy in the most difficult situation since last century's Great Depression. In the face of the crisis, countries and the international community have taken various measures to address it. [para. 2] (...)

\section{The global financial crisis is a challenge for the whole world. [para. 8] (Wen Jiabao, January 28, 2009)}

The excerpts indicate that the current global economy is not a durable economic system. The definite nominal groups 'the financial crisis', 'the global financial crisis', and 'the ongoing international financial crisis' all explicate that the global economy has been interrupted by the financial turmoil, but which is 'rarely seen in history'. The financial crisis in the age of global liberalism has actually affected the economic progress of developing countries and industrially advanced ones as well (e.g. China and USA). The 2008 financial crisis is a blow to the global economic project. It puts at risk both the global economic system and its material processes such as free market as an author says 'The ongoing financial crisis has landed the world economy in the most difficult situation' and 'is a challenge for the whole world'(4). Furthermore, circumstance of time 'since last century's Great Depression' and the nominal groups 'This financial crisis' in (2) and 'the global financial crisis' in (4) all presuppose that such crisis has never emerged in the era of globalization. The text also shows that the cause of the financial crisis is recognizable. For example, 'when booming housing markets began to decline' (2); nevertheless, the agency that precipitated the crisis is not identifiable. The verbal group 'was ignited' (2) is a passive form in which the actor of the material process of the verb 'ignited' is in doubt. However, the impact 'brings together government leaders, business people, experts and scholars of different countries to jointly explore ways to maintain international financial stability' (4). This is because economy and politic work closely during the global financial crisis (Fairclough \& Fairclough, 2011). Although it is not explicitly stated, the responsibility of the crisis should be on big tycoons, such as Fannie Mae, Freddie Mac and Lehman Brothers that ignited the U.S. financial instability (e.g. see McDonald \& Robinson, 2010). The authors who construct the texts admit that the financial crisis hinders the process of prevailing global economic processes, for example as in 'We are living through the first financial crisis of this new global age' (1), 'The financial crisis was ignited when booming housing markets began to decline' (2), 'Protectionism has swept across the world in the face of the financial crisis' (3) as well as in 'The ongoing international financial crisis has landed the world economy in the most difficult situation since last century's Great Depression' (4). The verbal groups 'was ignited', 'has swept' and 'has landed' imply that capitalist economic system is not to be blamed for the financial crisis.

The excerpts demonstrate that the authors see the global financial crisis as a challenge and an advantageous event as in 'The global financial crisis is a challenge for the whole world' (4) and 'The Financial Crisis Is Also an Opportunity to Create New Rules for Our Global Economy' (1). They linguistically and socially regard the crisis as a good thing. They textually construct the crisis as a natural socio-economic process; they perceive it as a personalized process that requires a political intervention. Ideologically, this is part of the process of globalization in which that nobody is in charge of, thus 'the whole world', 'the international community' and passive 'was ignited'. Consequently, countries in the world have to adapt to globalization processes in accordance with their own politic and economic strategies (Flowerdew, 2002).

The nominal group 'financial crisis' can grammatically become the initial participants of the clauses e.g. 'the (global) financial crisis is ...' and does not require the material or mental processes. This is because 'the financial crisis' is seen an economic phenomenon as if it happened by itself. But when the economy gets entangled in politic, humans as the animate agency must take over the matter. The excerpts below illustrate:

(5) We must deal with more than the symptoms of the current crisis. We have to tackle the root causes. (Washington Post, October 17, 2008, para. 7)

(6) Secondly, we must ensure that markets, firms, and financial products are properly regulated. [para. 19] (...)

Third, we must enhance the integrity of our financial markets. [para. 20] (...)

Fourth, we must strengthen cooperation among the world's financial authorities. (...) We should also reform international financial institutions such as the IMF and the World Bank, which are based largely on the economic order of 1944. (...) we should move forward with other reforms to make the IMF and World Bank more transparent, accountable, and effective. [para. 21] (George Bush, November 13, 2008)

(7) As the saying goes, "A fall in the pit, a gain in your wit," we must draw lessons from this crisis and address its root causes. In other words, we must strike a balance between savings and consumption, between financial innovation and regulation, and between the financial sector and real economy. [para. 2] (...)

We should encourage regional monetary and financial cooperation, make good use of regional liquidity assistance mechanisms, and steadily move the international monetary system toward greater diversification. [para. 10] 
We should expand the regulation coverage of the international financial system, with particular emphasis on strengthening the supervision on major reserve currency countries. We should put in place a timely and efficient early warning system against crisis. We should introduce reasonable and effective financial regulatory standards (...). We should tighten regulation of financial institutions and intermediaries and enhance transparency of financial markets and products. [para. 11] (Wen Jiabao, January 28, 2009)

In the excerpts above, the social actors of the clauses are human with material process verbs 'enhance', 'strengthen', 'strike', 'expand', 'reform' and 'tighten', among others. These verbs collocate with deontic modality 'must' and 'should', implying a high judgment and confusion as well. This linguistic process characterizes the discourse of global economy during the financial crisis as the state leaders and experts are searching for new strategies for the global economy. When dealing with new economic strategies, the authors put forward their arguments with the material process verbs.

The animate social agents are central in dealing with political economy during the crisis. Therefore, the first person plural 'we' constitutes the actors. In contrast, the free market economic practices can run without the government intervention, the so-called laissez-faire policies of the de-regularized. Consequently, characterized by the linguistic process of nominalization or reification, 'globalization' is regarded as a self-process phenomenon in the absence of animate agency. The excerpt below illustrates:

(8) The reforms I have outlined are vital to ensuring that globalization works not just for some but for all hard-pressed families and businesses in all our communities. (Washington Post, October 17, 2008, para. 9)

From this excerpt there is a tendency from the author to use a nominalization 'globalization' when addressing the social process of phenomenon. As a self-process phenomenon, globalization is ensured that it 'work not just for some but for all hard-pressed families and businesses in all our communities' although in reality it is transnational corporations that globalize the economy/trade/market and so forth. In the excerpt, Gordon Brown, the architect of global economy, obfuscates the agency. He sees globalization as the self-regulating process and thus linguistically inculcates it in terms of a grammatical metaphor (Halliday \& Matthiessen, 2014). The most intriguing aspect of the discourse is that globalization should not be seen from a negative point of view, but a positive one. In the excerpt, the viewpoint of globalization is internalized by a parallel structure of 'not just' ... 'but for all' resulting in a more positive perspective 'globalization works not just for some but all hard-pressed families and businesses in all our communities'.

The present globalization particularly with regard to the global economy is being mystified by the financial crisis. The crippling global financial crisis provides us with a sign that modern capitalism has reached the end of its time (Harvey, 2010). Surprisingly, free market ideologues and hyper-globalists claim that such a collapse exist not because there is no sufficient government involvement but because there is too much government involvement in the economy:

(9) History has shown that the greater threat to economic prosperity is not too little government involvement in the market, it is too much government involvement in the market. (Applause). (George Bush, November 13, 2008, para. 24)

The neoliberal language 'history has shown ... not too little government involvement in the market (but) too much government involvement in the market' provides an indication that Bush's economic thinking is far from the Keynesian paradigm in which government intervention is considerably important in a country's economy. The globalist discourse of economy views that the financial crisis emerges, because market is not deregulated, but intervened ('too much government involvement'). The social assumption here is that market can operate freely. This may be true in some way, but it does not necessarily mean that free market is not susceptible to a crisis when there is no government intervention. The statement in the extract (9) is a matter of politic. Thus, like a political system, an economic system is always in the state of flux and adherents either attempt to sustain the existing economic system through changes and transformation or seek for an alternative, but the latter is uncommon.

Economically it is admitted that the global crisis was triggered not only by too much presence of the government in political economy but also by excessive expansion of financial institutions, inappropriate economic policies, high consumption but low savings:

(10) This crisis is attributable to a variety of factors and the major ones are: inappropriate macroeconomic policies of some economies and their unsustainable model of development characterized by prolonged low savings and high consumption; excessive expansion of financial institutions in blind pursuit of profit; lack of self-discipline among financial institutions and rating agencies and the ensuing distortion of risk information and asset pricing; and the 
failure of financial supervision and regulation to keep up with financial innovations, which allowed the risks of financial derivatives to build and spread. (Wen Jiabao, January 28, 2009, para. 2)

At the same time, a confession is made that one way of tackling the crisis is by expanding demands:

(11) As a big responsible country, China has acted in an active and responsible way during this crisis. We mainly rely on expanding effective domestic demand, particularly consumer demand, to boost economic growth. (Wen Jiabao, January 28, 2009, para. 4)

There seems to be two contradictory discourses in the current global economy; the discourse of the financial crisis, where savings are needed and the discourse of consumption where spending is necessary. Confusion exists in the discourse of current global economy. However, state leaders are encouraged to have positive attitudes:

(12) The global financial crisis is a challenge for the whole world. Confidence, cooperation and responsibility are keys to overcoming the crisis. Confidence is the source of strength. [para. 8] (...)

Let us strengthen confidence and work closely together to bring about a new round of world economic growth. [para. 15] (Wen Jiabao, January 29, 2009)

(13) Today, the same sort of visionary internationalism is needed to resolve the crises and challenges of a different age. And the greatest of global challenges demands of us the boldest of global cooperation. [para. 4]

The old postwar international financial institutions are out of date. They have to be rebuilt for a wholly new era in which there is global, not national, competition and open, not closed, economies. International flows of capital are so big they can overwhelm individual governments. And trust, the most precious asset of all, has been eroded. [para. 5]

Confidence about the future is vital to building confidence for today. [para. 7]

To do this, we need cross-border supervision of financial institutions. [para. 8] (Washington Post, October 17, 2008)

(14) We live in a world in which our economies are interconnected. [para. 4] (...)

We must strengthen cooperation among the world's financial authorities. [para. 21] (George Bush, November 13, 2008)

The authors argue that the financial crisis is solvable when world leaders have 'confidence', 'trust' and are willing to 'work together' and 'strengthen cooperation'. The discourse from other fields is incorporated into the global economic discourse. From a political economy point of view, financial crisis is intrinsic in capitalism itself; it is the means by which it renews itself (Harvey, 2010). But this phenomenon is not articulated in the discourse of financial crisis. It can be true that global capitalism has opportunities to renew itself through productivity only if the goods and services the giants produce have a strong demand for high returns. Global cooperation is constituted by networked ('interconnected') economic systems that facilitate exchanges of information, goods, capital, and labor. The very structure of this network is vulnerable to severe impacts resulting from socio-political dynamics of the local systems. Malfunction in any point of this network would easily spread, creating damage to the entire system (McDonald \& Robinson, 2010). Such risk can exist in the global financial system constituted by a network of local independent financial institutions. If one local institution experiences a breakdown, the whole network will be exposed to fatal risk; therefore, there is a need for a 'cross-border supervision' (13). George Bush argues that 'We live in a world in which our economies are interconnected', but the interconnected economies are the most vulnerable to a crisis (Harvey, 2010). This is a risk of globalization. The risk of the so-called hyper-globalization is even worse when there is no circulation of 'trust' among the actors to whom the system is bestowed. Hyperglobalist frequently pass this phenomenon unchecked. If the circulation of trust grows thin, the whole financial system will get into a recession and finally collapse (McDonald \& Robinson, 2010). For example, Iceland that is financially 'interconnected' collapsed in a matter of weeks. Furthermore, the impact of crisis affects both local and global society, such as the collapse of the giant investment bank Lehman Brothers, which has institutionally contributed to the recession of American economy and finally the world economy.

Altogether the context of the U.S. and China texts is concerned with the economy in crisis. However, their contexts seem to be different in the course of history. The USA has always been a liberal country that is contingent on and allows for the free market impulse through competition in a single marketplace. That said, for a long time, the USA has been on the capitalist stance by liberalizing the system of trade and market as revealed in the excerpts below: 
(15) Free market capitalism is far more than economic theory. It is the engine of social mobility - the highway to the American Dream. (...). [para. 28]

The record is unmistakable: If you seek economic growth, if you seek opportunity, if you seek social justice and human dignity, the free market system is the way to go. (Applause.) And it would be a terrible mistake to allow a few months of crisis to undermine 60 years of success. [para. 31]

The world will see the resilience of America once again. We will work with our partners to correct the problems in the global financial system. We will rebuild our economic strength. And we will continue to lead the world toward prosperity and peace. [para. 37] (George Bush, November 13, 2008)

Americanism and the hegemony exist in the excerpt above. The nominal groups 'the American Dream' and 'the resilience of America' are two entities that can only refer to the USA. The author argues that 'social mobility', 'social justice' and 'human dignity' is attained through 'free market capitalism'. The clause 'the world will ...' and 'we will lead ...' represent the U.S. contested dominance of global economy.

China, on the other hand, is a former communist country that heavily relied on an economic system characterized by the collective ownership of property and by the organization of labor for the common advantage of all members as well as a system of government in which the state plans and controls the economy. A single, often authoritarian party holds power, claiming to make progress toward a higher social order in which all goods are equally shared by the people. Production facilities are state-owned and production decisions are made by official policy and not directed by market action.

In the present situation however even China seems to be dependent on the global market and has to follow and abide by the system of neoliberalism and global capitalism in struggle for dominance in the global economy. This statement is supported by the discursive practice in the strategic text:

(16) I want to reaffirm here China's abiding commitment to peaceful, open and cooperative development. China is ready to work with other members of the international community to maintain international financial stability, promote world economic growth, tackle various global risks and challenges, and contribute its share to world harmony and sustainable development. (Wen Jiabao, January 28, 2009, para. 14)

The excerpt above indicates that China is now firmly in support of the global system of economy even in the face of financial turmoil. The verbal group 'reaffirm' presupposes that China has been consistent in promoting 'world economic growth'. China is therefore ready to cooperate with other nations to 'maintain international financial stability'. Although not asserted, this political economic stance emerges because China is a world major exporter and therefore its leaders are willing to 'tackle various global risks and challenges' for 'world harmony and sustainable development'.

Wen Jiabao articulated this statement because he wanted to look 'good' to other leaders of state, chiefs of central banks, and foreign policymakers. The prepositional phrase 'with other members of the international community' and nominal groups 'cooperative development', 'world economic growth' and 'world harmony' illustrate Jiabao's political economic stance in which China is a committed country in promoting the well-being of the world society. This political economic position of China is compatible with that of the USA in which Bush's statement (15) sees 'working with partners' and 'rebuilding our economic strength' as the required strategies for economic recovery.

Altogether the analysis of global economic discourse during the global financial crisis provides us with an account that both the USA and China are textualizing the discourse of global economy in a similar socio-political context, namely, being engaged in promoting world economic growth even though national interests are inevitable. We now turn to the main standpoint and argumentation structures of the global economic discourse during the financial crisis.

\subsection{Structure of Argumentation in Discourse of Global Economy}

During the global financial crisis, state leaders, free-market economists and even newspaper columnists take part in debating the issue. The focal standpoint of their arguments internalizes a lasting socio-economic belief. The global economy is argumentatively treated in discourse as an inevitable economic logic that is not possible for turning back. The best way to uncover the construction of this logic is by dismantling the argumentation. The argumentation structure here is analyzed according to the pragma-dialectical approach, which is based on the principles of maximally argumentative analysis and maximally argumentative interpretation (van Eemeren at. al, 2002). Numbers symbolize the arguments and sub-arguments of each text. Since each text contains multiple arguments, the numbers appear in sequence. The bracketed numbers with apostrophe indicate implied arguments or implied sub-arguments. The structure of arguments is set out in Table 1. 
Table 1. The Arguments on Global Economy in Four Strategic Texts during the Global Financial Crisis

\begin{tabular}{|c|c|c|}
\hline \multicolumn{2}{|l|}{ Title, source and author } & \multirow{2}{*}{$\begin{array}{l}\text { Structure of argumentation } \\
\text { This is the first financial crisis of the new global age. }\end{array}$} \\
\hline Out of the Ashes & 1 & \\
\hline \multirow{6}{*}{$\begin{array}{l}\text { Washington Post, Gordon } \\
\text { Brown, October 17, } 2008\end{array}$} & 2 & The global financial crisis requires global solutions. \\
\hline & 2.1 & We have to rebuild the new international financial institutions. \\
\hline & 2.2 & We need confidence to resolve the global financial crisis. \\
\hline & 2.3 & We need the boldest global cooperation to solve the crisis. \\
\hline & 2.4 & We have to recapitalize our banks across many continents. \\
\hline & 3 & $\begin{array}{l}\text { The financial crisis is a defining moment and an opportunity to } \\
\text { create new rules for our global economy. }\end{array}$ \\
\hline Financial Markets and & 1 & The financial crisis was unavoidable. \\
\hline World Economy & 1.1 & $\begin{array}{l}\text { The massive inflow of foreign capital and easy credits affected the } \\
\text { housing market. }\end{array}$ \\
\hline \multirow{11}{*}{$\begin{array}{l}\text { George Bush, November 13, } \\
2008\end{array}$} & 1.2 & The financial crisis was ignited when housing markets declined. \\
\hline & 2 & We need broader reforms to strengthen the global economy. \\
\hline & 2.1 & Our nations must make our financial markets more transparent. \\
\hline & 2.2 & $\begin{array}{l}\text { We must ensure that markets, firms, and financial products are } \\
\text { properly regulated. }\end{array}$ \\
\hline & 2.3 & We must enhance the integrity of our financial markets. \\
\hline & 2.4 & $\begin{array}{l}\text { We must strengthen cooperation among the world's financial } \\
\text { authorities. }\end{array}$ \\
\hline & 3 & $\begin{array}{l}\text { Capitalism is the most efficient and just way of structuring an } \\
\text { economy. }\end{array}$ \\
\hline & $\left(3.1^{\prime}\right)$ & (Free market capitalism should be implemented by all nations.) \\
\hline & 3.2 & Free market capitalism is the engine of social mobility. \\
\hline & $\begin{array}{l}3.3 \\
(3.3 .1\end{array}$ & $\begin{array}{l}\text { The crisis was not a failure of the free market system. } \\
\text { (Free-market capitalism should not be blamed for the financial } \\
\text { crisis.) }\end{array}$ \\
\hline & 4 & $\begin{array}{l}\text { We face this financial crisis together and we need to defend } \\
\text { capitalism together. }\end{array}$ \\
\hline \multirow{4}{*}{$\begin{array}{l}\text { Strengthen Confidence and } \\
\text { Work Together for a New } \\
\text { Round of World Economic } \\
\text { Growth }\end{array}$} & 1 & This financial crisis is the most severe since the Great Depression. \\
\hline & 2 & The global financial crisis is a challenge for the whole world. \\
\hline & 2.1 & We must restore market confidence. \\
\hline & 2.2 & We need to deepen international economic cooperation. \\
\hline \multirow{3}{*}{$\begin{array}{l}\text { Wen Jiabao, January } 28 \\
2009\end{array}$} & 2.3 & We should reform the international financial system. \\
\hline & 2.4 & $\begin{array}{l}\text { We should hold responsibilities and obligations to minimize the } \\
\text { damage caused by the international financial crisis. }\end{array}$ \\
\hline & 3 & Confidence, cooperation and reform are keys to tackling the crisis. \\
\hline \multirow{2}{*}{$\begin{array}{l}\text { Compromises Needed to } \\
\text { Save Global Economy }\end{array}$} & 1 & Global economy is on the verge of collapse. \\
\hline & 1.1 & Protectionism has swept across the world in the face of the crisis. \\
\hline \multirow[t]{3}{*}{$\begin{array}{l}\text { China Daily, Liu Junhong, } \\
\text { April 02, } 2009\end{array}$} & 1.2 & $\begin{array}{l}\text { European countries and the US hold different views towards } \\
\text { policies on international finance due to protection of their } \\
\text { interests. }\end{array}$ \\
\hline & 2 & $\begin{array}{l}\text { The G20 summit should coordinate policies and strategies among } \\
\text { different powers to save the world economy. }\end{array}$ \\
\hline & 3 & Compromises needed to save global economy. \\
\hline
\end{tabular}

The overall construction of arguments on the global economy during the financial crisis is in the form of problem-solution structure. The major standpoint of arguments as set out in Table 1 can be amalgamated by means of a modus ponens analysis, that is, an "if...then..." statement (van Eemeren et al., 2002, p. 57), which can be illustrated as follows:

Premise 1: If global economy is faced with a financial crisis, then we must find solutions to the crisis. 
Premise 2: Global economy is faced with a financial crisis.

Conclusion: Therefore, we must find solutions to the crisis.

The conclusion of argumentation in the discourse is that global economy must sustain even though it is faced with the financial crisis. The standpoint is defended by multifaceted arguments as illustrated in Table 1. The arguments encourage the restructuring of chaotic global economy through opportunity, confidence, and challenge, which is regarded as the driving forces for recovery. The major standpoint is embedded in the discourse by a mixture of discursive processes from political economy, monetary economics and sociology of capitalism as well. The discourses from these disciplines are articulated together in the discourse of financial crisis. The global economic project is regarded as an exorable economic logic that must be maintained all time.

The first person plural 'we' of the arguments in Table 1 is the exclusive-community 'we' that refers to leaders of state and monetary policymakers. The arguments illustrate that the authors regard the global financial crisis as a 'defining moment for the world economy'. They also see the crisis as an opportunity, i.e., 'the opportunity to create new rules', presupposing that the global economy needs 'new rules' and 'compromises', because the practices of existing global economy are assumed to have fulfilled national interests, for instance, protectionism. Altogether the arguments reveal that, although it may be at stake, the global economic discourse and its real manifestation is worth fighting for. The discursive struggle is not only in the form of economy, but also in political and social aspects. The following subsections will extend our discussion about the major standpoint and argumentation structures to include the rhetorical means of persuasion.

\subsection{Strategic Maneuverings in Discourse of Global Economy}

\subsubsection{Topical Selection}

The discourse of global economy is strategically maneuvered through topical selection. The topic of the discourse during the global financial crisis seems to suggest that the authors are defending the ideas of capitalist globalization. Whether it is clearly stated in title of the press like 'Compromises needed to save global economy' (China Daily, April 02, 2009) and in the headline 'The financial crisis is also an opportunity to create new rules for our global economy' (Washington Post, October 17, 2008) or it can be derived from the overall propositional content of text, the topic of discourse is all about the struggle in the current global economy. Like any other social problem, the global financial crisis can be a 'defining moment', 'challenge' or 'opportunity'; hence an active social process that is hard but needs to be tackled.

The topic choices are made most relevant to the context of situation (Chouliaraki \& Fairclough, 1999) and the mental model (van Dijk, 2009) as part of a bigger issue in the current process of the global economy. Since the global economy affects everyone, its discourse topics correspond to the field of social life, that is, the current global economic growth in the chaotic situation. These topics are raised and their arguments are put forward, because they are potential for measuring the economic development of the world economy. The topical potential suggests an economic transformation from the current situation to a better condition, discursively through legitimization as in 'Compromises needed to save global economy' and inexorable economic logic as in 'We live in a world in which our economies are interconnected.'

The texts are bound to the conundrum of global economy and its survival in the age of globalization. For example, the Op-Ed article by Gordon Brown 'Out of the Ashes' (Washington Post, October 17, 2008) and his attention-getting sentence 'This is a defining moment for the world economy' is compatible with the topic of article. This article was written in response to the reform of the international financial system by the European Union and the USA. This Op-Ed article is persuasive. From a transdisciplinary paradigm, what one can detect from the context of its headline and the article as a whole is that recontextualization is mobilized - a movement from the economy 'is' to the politic 'ought'; the economy is nationally sluggish. Therefore, it needs restructuring between economy and politic and rescaling from the national, regional to the global economy, from closed to open economies (13). In other words, it is a system of neoliberal economy that operates here - the economic structure that attempts to restrict the trade regulation of the government by 'new rules' but allows it to be decided by the global market. New rules can include tight supervision 'To do this, we need cross-border supervision of financial institutions' (13). Some countries have to supervise and regulate others in terms of financial matters. The hidden agenda beyond the discourse of supervision within the global economy is the legitimization of dominance and control of the developed economies over the least developed ones. The dominance and control are usually exercised by manipulating the mind of the public through discourse (van Dijk, 2009). 
To accord with the audience demand (to be discussed in Subsection 4.3.2), the discourse topic is selected from a potential of issues. For example, the macro topic of George Bush's speech was about the summit's ways to tackling the financial crisis entitled 'Financial markets and world economy':

(17) The leaders attending this weekend's meeting agree on a clear purpose - to address the current crisis, and to lay the foundation for reforms that will help prevent a similar crisis in the future. We also agree that this undertaking is too large to be accomplished in a single session. The issues are too complex, the problem is too significant to try to solve, or to come up with reasonable recommendations in just one meeting. So this summit will be the first of a series of meetings. [para. 5]

It will focus on five key objectives: understanding the causes of the global crisis, reviewing the effectiveness of our responses thus far, developing principles for reforming our financial and regulatory systems, launching a specific action plan to implement those principles, and reaffirming our conviction that free market principles offer the surest path to lasting prosperity (Applause.) [para. 6]

Part of this excerpt indicates that George Bush speaks for the other state leaders 'The leaders attending this weekend's meeting agree on a clear purpose ... and reaffirming our conviction that free market principles offer the surest path to lasting prosperity'. At the beginning of his speech, George Bush introduces the topic i.e. the global financial crisis and offers suggestions of how governments in the world should deal with it cooperatively, but later he links the financial crisis to the resonance of free market capitalism:

(18) Like any other system designed by man, capitalism is not perfect. It can be subject to excesses and abuse. But it is by far the most efficient and just way of structuring an economy. [para. 27]

Free market capitalism is far more than economic theory. It is the engine of social mobility - the highway to the American Dream. It's what makes it possible for a husband and wife to start their own business, or a new immigrant to open a restaurant, or a single mom to go back to college and to build a better career. It is what allowed entrepreneurs in Silicon Valley to change the way the world sells products and searches for information. It's what transformed America from a rugged frontier to the greatest economic power in history-a nation that gave the world the steamboat and the airplane, the computer and the CAT scan, the Internet and the iPod. [para. 28]

Ultimately, the best evidence for free market capitalism is its performance compared to other economic systems. Free markets allowed Japan, an island with few natural resources, to recover from war and grow into the world's second-largest economy. Free markets allowed South Korea to make itself into one of the most technologically advanced societies in the world. Free markets turned small areas like Singapore and Hong Kong and Taiwan into global economic players. [para. 29]

Cuba, once known for its vast fields of cane, is now forced to ration sugar. And while Iran sits atop giant oil reserves, its people cannot put enough gasoline in its- in their cars. [para. 30] (George Bush, November 13, 2008).

This topic shift occurs because George Bush is talking in front of American audience, but for a global impact. He takes the opportunity of economic crisis issue for granted and contextualizes it into preaching the gospel of capitalism. This topic shift does ideological work; it promotes capitalism. The ideology attaches to the vocabulary 'free market', 'engine of social mobility' and 'other economic systems'. The main topic of argumentative discourse is manifested in the title 'Financial Markets and the World Economy', but later it derails to free markets and capitalism. The purpose of speech was to outline the steps that America and its partners are going to take to overcome this financial crisis. But the argumentation shifts; it is rhetorically correct, but argumentatively fallacious. In other words, the argument seems to be sound, but is not so. This is because it violates the rule that the proponent must defend the topic and observes the relevance rule (van Eemeren et al., 2002). It is thus a good argument, but with a bad process. When the argument derails, George Bush social identity also shifts from the president of the United States to the mouthpiece of capitalism. Simply put, the speech is socially and cognitively defending capitalism as it is clearly asserted in 'Like any other system designed by man, capitalism is not perfect. It can be subject to excesses and abuse. But it is by far the most efficient and just way of structuring an economy' (18). The denial linker 'but' and the superlative 'most efficient' presuppose as if other economic systems are less efficient and not just.

In a different part of the speech, George Bush implies that the other models of economy-Cuba's communist and Iran's Islamic socialist - are detrimental and backward, as in 'Cuba, once known for its vast fields of cane, is now forced to ration sugar. And while Iran sits atop giant oil reserves, its people cannot put enough gasoline in its- in their cars' (18). The author raises the topic that is easier to handle and most agreeable to the audience. He picked up the less 
developed countries and presented their weaknesses. He undermines the development of these countries. He does not realize that the development of these countries are not always attributed to the economic systems they hold, but to the global discriminations in an opportunity due to the hegemonic political economic policies such as embargos, blockades and limited accesses to technological advances. There is also a polarization in the excerpt. The USA is represented in a positive way while Cuba and Iran are represented negatively.

\subsubsection{Adaptation to Audience Demand}

Argumentative discourse does not always look neutral to all audiences. The fact that George Bush chose the Federal Hall National Memorial as the location for the speech delivery is political. The speech is strategically maneuvered in order to show that Americans are steadfast in holding their positions in coping with practices of the global economy even during the financial crisis. After all, the speech was delivered several days before the G20 talks about the global economic crisis. George Bush put forward the argument that is not only easy to handle and but also most agreeable to audience as in (18). In the case of the context and discourse topic there is a dialectical relation between the discourse of global economy and venue. George Bush could have addressed his speech under the title 'Financial Markets and World Economy' at the National Cathedral as he did when he responded in the rival speech to the $9 / 11$ attacks. But this speech is not about war on terror. Thus the Federal Hall National Memorial is one of the best places. What one can learn from the speech is the evidence that discourse on a particular social problem has social relations with other social entities (Fairclough, 2010). The embedded clause 'what makes it possible for a husband and wife ...' (18) presumes that other economic systems cannot do better than 'free market capitalism'. Economic hardship of the "uncounted for" is marginalized. Therefore, Bush's statement can be ideological. As covered by Al-Jazeera and RT between August and November 2011, the statement is contradictory to the fact; hundreds of Americans had to sleep on their pick-up trucks on the street amid the seizure of their homes by the capitalist investment banks. More American children are now dependent on their food stamps. But George Bush is still eager to promote the idea that capitalism 'transforms' America into a great economy, and 'changes' the way people buy and sell their products, without considering that capitalism is beneficial to a few people but detrimental to the others. In other parts of speech [para. 34], George Bush persuades the audience to believe that the past failures of capitalism in 1929, 1940s and 1970s were restored by the free-market economy. The most apparent evidence that adaptation to audience demand emerged in Bush's speech is when he links the speech to capitalism and the audience endorse it with applauses e.g. in paragraphs 6, 24, 25 and 31, among others.

Discourse and social reality, as was conceptualized Section 2, have a dialectical relationship. The dialectical interdependence between discursive and non-discursive aspects provides the authors with resources for saying things according to communication setting. For example, Chinese Premier Wen Jiabao delivered a speech at the opening ceremony of the World Economic Forum (WEF) meeting in Davos on January 28, 2009. The speech was attended by the WEF chairperson Professor Schwab, members of the forum, governors of central banks, corporate managers, market analysts and the like. This all has its relevance to China's role in the global economy and these people determine how the global economy propels. The speech was delivered with contents that were in accordance with audience demand. Premier Wen Jiabao bows to the free market ideology and agrees to the developed countries' proposal of finding solutions to the global financial crisis. For such a maneuvering strategy, Wen Jiabao makes persuasive statements in the 2009 WEF meeting that:

(19) As a big responsible country, China has acted in an active and responsible way during this crisis. (Wen Jiabao, January 28, 2009, para. 4)

The verb group 'has acted' and circumstance of manner 'in an active and responsible way' presupposes that people thought China did not act in such a way. At the end of that speech Wen Jiabao convincingly states:

(20) We are committed to reform, opening-up and win-win progress. [para. 7] (...)

The global financial crisis is a challenge for the whole world. Confidence, cooperation and responsibility are keys to overcoming the crisis. Confidence is the source of strength. The power of confidence is far greater than what can be imagined. [para. 8] (...)

I want to reaffirm here China's abiding commitment to peaceful, open and cooperative development. China is ready to work with other members of the international community to maintain international financial stability, promote world economic growth, tackle various global risks and challenges, and contribute its share to world harmony and sustainable development. [para. 14] (Wen Jiabao, January 28, 2009).

This partly reused excerpt demonstrates that, although Wen Jiabao does not use the ideological word 'global' for the context of economic growth, he uses it for 'risk' and 'challenges'. This is the political economic strategy of China from 
the discursive perspective. The articulation of 'the commitment' agrees with audience demand. If the utterance had been 'I want to reaffirm here China's abiding commitment to free, global economic market', it would sound provocative. The WEF members would think of emerging China as the economic rival of the dominant USA. But given the fact that his authority as a leader from China is concerned with capital (economic, social, cultural), even the socialist Wen Jiabao is transforming China into the global capitalist economy. This transformation is discursively manifested through the audience demand in terms of conciliatory words 'reform' and 'opening-up' as in 'We are committed to reform, opening-up and win-win progress.'

The discourse of 'opening-up' is enacted to be less provocative. Wen Jiabao uses it as an indicator of globalist style, denoting liberal economy. But politically as an emerging economic country that wakes from its communist orthodoxy, for China the discourse of 'opening-up' is in some way well-matched with the globalist audience's expectation that China has woken up from its communist slumber and embraced the free market ideology. This does not deny that the contents of the speeches are in general still tied with China's national economic interests, where banal nationalism is self-evident in that one's nationality is inevitably articulated in front of the general public. The discourse of 'opening-up' portrays China's involvement in the world economic arena by rescaling its national interests.

The use of nominal groups 'challenge', 'confidence' and 'cooperation' in (20) is a discursively strategic bow to the audience demand of other influential figures, the international political economists, and certainly the WTO and the IMF. After all, Jiabao's counterparts, Gordon Brown and George Bush, use the same lexical items to address the issue. The bow is not physical but semiotic, repeating and borrowing what one has said and agreed upon.

\subsubsection{Presentational Choices}

From a genre perspective, the strategic texts are all talking about the same social problem, the same social reality, that is, the meltdown of global economy vis-à-vis in the global financial crisis. The global economy is generally argued as real - the concrete results have been achieved. But sometimes it is imagined, which no more than the intellectual language game. This imagination is presented through 'conditional if' discourse as illustrated in the following excerpts:

(21) In the next few weeks, we need to show the same resolve and spirit of cooperation to create the rules for our new global economy. If we do this, 2008 will be remembered not just as a year of financial crisis but as the year we started to build the world anew. (Washington Post, October 17, 2008, para. 11)

(22) The record is unmistakable: If you seek economic growth, if you seek opportunity, if you seek social justice and human dignity, the free market system is the way to go. (George Bush, November 13, 2008, para. 31)

The conditional clauses in (21) and (22) are part of 'irrealis' statements (Fairclough, 2003); they are assumptions and predictions. The enactment, discursive formation of such an argumentation strategy as conditional clauses is ideologically motivated. The use of the conditional "if" for the discourse topic strategically shapes a populist discourse that free market is an effective system to gain economic prosperity and that everybody is responsible to contribute. That is, the discourse supports free trade of global capitalism and belittles its negative impacts on the small firms, and the owners and their family. The 'spirit of cooperation' (21), the 'free market' (22) and its '60 years of success' (15) are naturalized as the indicators of economic globalization success. The 70 years of success of the socialist system, as that of USSR, is not confessed but belittled (18). The general technique of argumentation is thus substantially manifested through the derailment of the arguments, that is, overall the arguments are about tackling the global financial crisis but at the same time promote capitalism.

In addition, references are often made to advances of technology as in (18) and statistical figures (below) to indicate the success of the rescaled economy. The assertion concerning statistical figures strategically polishes the argumentation:

(23) The Chinese Government has rolled out a two-year program involving a total investment of RMB 4 trillion, equivalent to $16 \%$ of China's GDP in 2007. (...) This two-year stimulus program has gone through scientific feasibility studies and is supported by a detailed financial arrangement. RMB 1.18 trillion will come from central government's budget, which is expected to generate funds from local governments and other sources. [para. 4]

(24) China's economy is in good shape on the whole. We managed to maintain steady and relatively fast economic growth in 2008 despite two unexpected massive natural disasters. Our GDP grew by 9\%. CPI was basically stable. We had a good grain harvest for the fifth consecutive year, with a total output of 528.5 million tons. Eleven million and one hundred and thirty thousand new jobs were created in cities and towns. [para. 6] (Wen Jiabao, January 28, 2009) 
The rhetorical strategy of presentational choices by referring to the statistical figures for generalization, as illustrated above, is to convince the discourse participants. Such argumentative techniques of presentational choices (van Eemeren; 2010) and the statistical method (Fairclough \& Thomas, 2004) characterize the discourse of global economy. The economic growth is argued to be a direct impact of free-market economy, 'reform' and 'opening up' which then is translated into the statistical figures.

The language of statistical methods is manifested by the nominal groups 'a total investment of RMB 4 trillion' and ' $9 \%$ growth of GDP'. No information is provided whether the growth is based on all layers of society or on the wealth of a few elites and business tycoons. The account of global economic issues through the presentational choices such as 'conditional if' and the uses of statistical figures constitute part of the discursive construction of the thriving global economy. But when a reality check is conducted, the global economic growth is very much in injustice, the widening gap between the rich and poor.

\section{Conclusion}

This paper has examined the discursive construction of globalization, especially the global economy as articulated in the strategic texts from the CDA and argumentation perspectives. We can conclude from the discussion that the discourse of global economy is constructed through universalization and naturalization of its past success. Global economy is seen as an inexorable economic logic driven by such factors as free market, competition and opening-up. The prevailing practices of this economic logic were mired by the 2008 financial crisis. The resonance of this economic system is thus selected in the speeches of political elites and mass media coverage, so that people have insights of the current progress of global economy.

The authors reconstruct and defend the discourse of global economy in the period of financial crisis by persuasive argumentation. The authors select the topics that are to handle and most agreeable to the audience. The arguments contain a problem-solution structure. The financial ruin is arguably treated as challenges and opportunities to create new rules for the global economy. Practices of global economy must be maintained even in the epoch of the financial crisis. The global leaders are encouraged to have confidence, restore global economic cooperation and work together to tackle the crisis. The authors use deontic modality (must, have to, should) plus verbs of material processes ('enhance', 'strengthen', 'strike', 'expand', 'reform') in presenting solutions to the crisis. The topics of discussion about the financial crisis are also used to promote the advantages of such issues as free-market capitalism and economic reforms to create new economic strategies but the same system. Irrealis statements and statistic figures can be enacted to anticipate the success of global economy.

The analysis implies that global economy is inevitable. The world civil society therefore should adapt the real programs, but needs to transform and emancipate the ones that are not compatible with the discursive practices of globalization agenda that preach to create the economic well-being of people through equity of global transformation. For that reason, there is a need of acquiring critical language awareness for the world society on the importance of understanding both the discursive processes and the material processes of globalization.

\section{Acknowledgement}

I would like to thank the two anonymous reviewers and the editor of this journal for their useful comments on the first version of this paper. I have attempted to revise it by following their comments meticulously.

\section{References}

Adams, G. F. (2011). Globalization: Today and tomorrow. London: Routledge.

Bauman, Z. (2013). Globalization: The human consequences. London: John Wiley \& Sons.

Beck, U. (2000). What is globalization? Cambridge: Polity Press.

Castells, M. (1996). The rise of the network society. Cambridge, MA: Blackwell.

Chouliaraki, L. \& Fairclough, N. (1999). Discourse in late modernity: Rethinking critical discourse analysis. Edinburgh: Edinburgh University Press.

Fairclough, N. (2003). Analyzing discourse: Textual analysis for social research. London: Routledge.

Fairclough, N. (2006). Language and globalization. London: Routledge.

Fairclough, N. (2010). Critical discourse analysis: The critical study of language (2nd ed.). London: Longman. http://dx.doi.org/10.4324/9780203809068.ch1

Fairclough, N. (2014). Language and power (3nd ed.). London: Routledge.

Fairclough, I. \& Fairclough, N. (2011). Practical reasoning in political discourse: The UK government's response to the economic crisis in the 2008 pre-budget report. Discourse \& Society, 22 (3): 243-268. http://dx.doi.org/10.1177/0957926510395439 
Fairclough, N. \& Thomas, P. (2004). Discourse of globalization and globalization of discourse. In D. Grant (Ed.) The Sage handbook of organizational discourse, pp. 380-396. London: Sage. http://dx.doi.org/10.4135/9781848608122.n18

Flowerdew, J. (2002). Globalization discourse: A view from the East. Discourse \& Society, 13 (2): $209-225$. http://dx.doi.org/10.1177/0957926502013002407

Gereffi, G. (1994). The organization of buyer driven global commodity chains. In G. Gereffi \& M. Korzeniewicz (Eds.) Commodity chains and global capitalism, pp. 95-122. Westport, CT: Greenwood.

Giddens, A. (1990). The consequences of modernity. Stanford, CA: Stanford University Press.

Gilpin, R. (1987). The political economy of international relations. Princeton, NJ: Princeton University Press.

Halliday, M.A.K. \& Matthiessen, C. (2014). Halliday's introduction to functional grammar (4th ed.). London: Routledge.

Harvey, D. (2010). The enigma of capital: And the crisis of capitalism (2nd ed.). New York: Oxford University Press.

Hasan, R. (2003). Globalization, literacy and ideology. World Englishes, 22 (4): 433-448. http://dx.doi.org/10.1111/j.1467-971X.2003.00311.x

Hay, C. \& Rosamond, B. (2002). Globalization, European integration and the discursive construction of economic imperatives. Journal of European Public Policy. 9 (9): 147-167. http://dx.doi.org/10.1080/13501760110120192

Held, D., McGrew, A., Goldblatt, D. \& Perraton, J. (1999). Global transformations: politics, economic and culture. Stanford, CA: Stanford University Press.

Hisrt, P. \& Thompson, G. (1996). Globalization in question. Cambridge: Polity Press.

Jessop, B. (2004). Critical semiotic analysis and cultural political economy. Critical Discourse Studies, 1 (2), 154-174. http://dx.doi.org/10.1080/17405900410001674506

Koh, A. (2005). Heteroglossic' discourses on globalization: A view from the 'East. Globalization, 2 (1): $228-239$. http://dx.doi.org/10.1080/14747730500202230

Kutter, A. (2014). A catalytic moment: The Greek crisis in the German financial press. Discourse \& Society, 25 (4): 446-466. http://dx.doi: 10.1177/0957926514536958

McDonald, L. G \& Robinson, P (2010). A colossal failure of common sense: The inside story of the collapse of Lehman Brothers. New York: Crown Business.

Monica, H. (2003). Globalization, the new economy, and the commodification of language and identity. Journal of Sociolinguistics, 7 (4): 473-492. http://dx.doi.org/10.1111/j.1467-9841.2003.00238.x

Ohmae, K. (1994). The borderless world: Power and strategy in the global marketplace. London: Harper Collins.

Peck, J. \& Theodore, N. (2007). Variegated capitalism. Progress in Human Geography, 31 (6): 731-772. http://dx.doi.org/10.1177/0309132507083505

Ritzer, G. (2009). Globalization: A basic text. Oxford: Blackwell.

Scholte, J.A. (2000). Globalization: A critical introduction. Basingstoke: Macmillan.

Sparke, M. (2013). Introducing globalization: Ties, tensions, and uneven integration. London: Blackwell.

Vaara, E., Sorsa, V. \& Pälli, P. (2010). On the force potential of strategy texts: A critical discourse analysis of a strategic plan and its power effects in a city organization. Organization, 17 (6): 685-702. http://dx.doi.org/10.1177/1350508410367326

van Dijk, T.A. (2009). Society and discourse. Cambridge: Cambridge University Press. http://dx.doi.org/10.1017/CBO9780511575273

van Eemeren, F.H. (2010). Strategic maneuvering in argumentative discourse: Extending the pragma-dialectical theory of argumentation. Amsterdam: John Benjamins. http://dx.doi.org/10.1075/aic.2

van Eemeren, F.H. \& Grootendorst, R. (2004). A systemic theory of argumentation: The pragma-dialectical Approach. Cambridge: Cambridge University Press.

van Eemeren, F.H., Grootendorst, R. \& Snoeck Henkemans, F.A. (2002). Argumentation: Analysis, evaluation, and presentation. Mahwah, NJ: Lawrence Erlbaum. 